\title{
MOLECULAR DETECTION OF invA AND hilA VIRULENT GENES IN SALMONELLA SEROVARS ISOLATED FROM FRESH WATER FISH
}

\author{
Sarah A. Allam ${ }^{1 *}$, Nader Y. Mostafa ${ }^{1}$, Ghada A. K. Kirrella ${ }^{1}$, Nesreen Z. Eleiwa², \\ Mohammed A. El-Magd ${ }^{3}$
}

${ }^{1}$ Food Control Department, Faculty of Veterinary Medicine, Kafrelsheikh University, 33516, Egypt, ${ }^{2}$ Animal Health Research Institute, Dokki, Giza, Egypt, ${ }^{3}$ Anatomy Department, Faculty of Veterinary Medicine, Kafrelsheikh University

*Corresponding Author: sara.alam9912@yahoo.com

\begin{abstract}
The present study was conducted to monitor the prevalence of salmonellae in fresh water fish in Gharbia governorate, Egypt. A total of 120 random samples of fresh water fish (Tilapia niloticus, Mugil cephalous and Clarias lazera, 40 of each) were analyzed bacteriologically for the presence of salmonella pathogens and were further identified using biochemical and serological tests. Positive samples were confirmed by polymerase chain reaction (PCR) through detection of common virulent genes invasion $A$ (invA) and hyper-invasive locus (hilA). The obtained biochemical and serological results revealed presence of seven different serotypes including $S$. typhimurium which was the most frequent one followed by $S$. enteriditis, $S$. infantis , $S$. virchow, $S$. heidelberg, $S$. wingrove and $S$. tsevie with a prevalence of $33.3 \%, 23 \%, 12.8 \%, 12.8 \%, 10.25 \%, 5 \%$ and $2.5 \%$, respectively. The obtained molecular results revealed presence of the two virulent genes in all the detected serovars with a total prevalence rate of $100 \%$ for invA gene and $66.6 \%$ for hila gene. These results reflected a high prevalence of salmonella species in fresh water fish which act as a potential source of food borne infection and constitutes a major concern for public health.
\end{abstract}

Key words: fresh water fish; salmonella; serotypes; invA; hilA; PCR

\section{Introduction}

Fish are considered as an excellent cheap source of high quality protein with very low cholesterol levels and large quantities of polyunsaturated fatty acids that cannot be synthesized by human metabolism $(1,2)$. However, fish are also considered as a major carrier for food borne pathogens as its natural habitat is extremely susceptible to pollution from domestic, industrial and agricultural discharges (3). Bacterial diseases in fish cause a serious threat not only to aquaculture industry but also on human health. Thus, it is not surprising to find that $12 \%$ of the food poisoning outbreaks associated with fish consumption are caused by bacteria including salmonella (4).

Salmonella, as a member of family enterobacteriacea, is a Gram negative rod shaped bacteria that contains more than 2500 serovars. Salmonella, which is considered as a common water-borne pathogen, apparently presents in the tissues of normal fish and represents no clinical signs. It can easily reach water through many 
routes, especially through sewage discharges, and can concentrate in fish tissues. It also can reach fish outside water through fish handling without following strict hygienic measures. When these contaminated fish were eaten raw or with quick inappropriate heating, the consumers would suffer from enteritis and typhoid fever. Despite extensive public health measures over the past century, salmonella remains the second leading cause of food-borne diseases worldwide (5). Accordingly, providing a safe, high quality and acceptable food to a consumer is considered a major goal for food processing industry. This can be applied by prompt and accurate isolation and characterization of salmonella and other food-borne pathogens which are the cornerstone required for proper control of food-borne diseases. This can be achieved using molecular identification of these pathogens by polymerase chain reaction (PCR) technique. The latter, is highly sensitive and more accurate method for bacterial isolation and identification, especially for salmonella sp. (6). Thus, our study was planned to identify the prevalence of salmonella species in fresh water fish in Gharbia Governorate, Egypt and to detect the common virulent genes of salmonella serovars using PCR technique.

\section{Materials and methods}

\section{Isolation of salmonellae}

A total of 120 random samples of fresh water fish including Tilapia niloticus, Mugil cephalous and Clarias lazera (40 of each) were collected from different markets in Gharbia governorate, Egypt. Samples were placed separately in sterile plastic bags in an ice box and transported immediately to the laboratory for bacteriological examination. According to ISO 6579 (2002) method [11]: $25 \mathrm{~g}$ of back muscles of each sample of fresh water fish were transferred to a homogenizer flask containing $225 \mathrm{ml}$ of sterile buffered peptone (1\%) and homogenized for $1 \mathrm{~min}$, then incubated at $37^{\circ} \mathrm{C}$ for $18 \mathrm{~h}$. According to ISO 6579 (2002) method: $1 \mathrm{ml}$ of each homogenate was inoculated separately into a tube of $9 \mathrm{ml}$ selenite-f- broth and incubated at $37^{\circ} \mathrm{C}$ for $18 \mathrm{~h}$ or $0.1 \mathrm{ml}$ was transferred to $9 \mathrm{ml}$ of Rappaport - Vassiliadis Soya broth
(RVS) and incubated at $42^{\circ} \mathrm{C}$ for $24 \mathrm{~h}$. A loopful from selective enriched broth was streaked onto plates of Xylose Lysine Deoxycholate (XLD) and incubated at $37{ }^{\circ} \mathrm{C}$ for $24 \mathrm{~h}$. Typical pink colonies with or without black center were picked up for further identification.

\section{Identification of salmonellae}

For microscopical identification, films from suspected colonies were prepared, fixed and stained with Gram stain showing Gram negative rod-shaped, motile bacilli that indicates salmonella pathogen. For biochemical identification, according to ISO 6579 (2002) method: purified isolates were examined by different biochemical reaction based on oxidase, urea hydrolysis, H2s production on tripple sugar iron, indole, methyl red, vogus-proskaur and citrate utilization tests. For biochemical identification, salmonella isolates were serotyped according to Kauffman (1974) method (7) for the determination of somatic $(\mathrm{O})$ and flagellar $(\mathrm{H})$ antigens using salmonella antiserum (DENKA SEIKEN Co., Japan).

\section{Molecular detection of salmonella virulent genes by multiplex PCR}

Bacterial DNA was extracted using QIA amp extraction kit following manufacturer's protocol and as previously described (8). Multiplex PCR was applied to amplify salmonella virulence genes invA and hila using specific primers as shown in table 1 . PCR reaction mixture $(25 \mu \mathrm{l})$ contained $5 \mu \mathrm{l}$ of bacterial DNA, $2.5 \mu \mathrm{l}$ of 10x Master mix (containing 1.25 U of Taq DNA polymerase, $1.5 \mathrm{mM} \mathrm{MgCl} 2$ and $2 \mu \mathrm{l}$ $10 \mathrm{mM}$ dNTP mix), $1 \mu \mathrm{l}$ of each primer (10 pmol) $15.5 \mu \mathrm{l}$ DNase free water. The PCR cycling protocol was applied as following: an initial denaturation at $94^{\circ} \mathrm{C}$ for $60 \mathrm{sec}$, followed by 35 cycles of denaturation at $94^{\circ} \mathrm{C}$ for $60 \mathrm{sec}$, annealing at $64^{\circ} \mathrm{C}$ for $30 \mathrm{sec}$ and extension at $72^{\circ} \mathrm{C}$ for $30 \mathrm{sec}$, followed by a final extension at $72^{\circ} \mathrm{C}$ for $7 \mathrm{~min}$. Finally, $5 \mu \mathrm{l}$ of each amplicon was electrophoresed in $1.5 \%$ agarose gel, stained with ethidium bromide and visualized and captured on UV transilluminator. A 100 bp DNA ladder was used as a marker for PCR products 


\section{Results}

\section{The prevalence of salmonella species}

The total prevalence rate of isolated salmonella was 32.5\% (39/120) in all fish with highest incidence rate in Mugil species (47.5\%, 19/39) followed by Clarias lazera $(30 \%, 12 / 39)$ and Tilapia niloticus $(20 \%, 8 / 30)$.

\section{Serotyping}

Salmonella isolates $(\mathrm{n}=39)$ were serotyped using "O" and " $\mathrm{H}$ " antisera and the results showed 7 different salmonella serotypes: $S$. typhimurium, S. enteritidis, S. infantis, S. virchow, S.Heidelberg, S. wingrove and S. tsevie with a total percentage of $33.3 \%, 23 \%, 12.8 \%$, $12.8 \%, 10.25 \%, 5 \%$ and $2.5 \%$, respectively. The prevalence of each serotype in each fish type was shown in Table 2.

\section{Incidence of virulence genes}

The incidence of invA and hilA virulent genes among the 7 salmonella serotypes as detected by multiplex PCR revealed prevalence of invA gene in all salmonella serotypes with a percentage of $100 \%$, hilA gene in only $66.6 \%$ of all serotypes (Table 3 and Fig. 1).

Table 1: The primer sequence of salmonellae used for PCR

\begin{tabular}{|l|l|l|l|}
\hline $\begin{array}{l}\text { Target } \\
\text { gene }\end{array}$ & Oligonucleotide sequence $\left(5^{\prime} \rightarrow 3^{\prime}\right)$ & $\begin{array}{l}\text { Product } \\
\text { size }(\mathrm{bp})\end{array}$ & References \\
\cline { 1 - 2 } invA $(F)$ & $5^{\prime}$ GTGAAATTATCGCCACGTTCGGGCA '3 & 284 & $(9)$ \\
\cline { 1 - 2 }$(R)$ & $5^{\prime}$ TCATCGCACCGTCAAAGGAACC '3 & & \multirow{2}{*}{$(10)$} \\
\cline { 1 - 2 } hilA $(F)$ & $5^{\prime}$ CTGCCGCAGTGTTAAGGATA '3 & 497 & \\
\hline hilA $(R)$ & $5^{\prime}$ CTGTCGCCTTAATCGCATGT '3 & & \\
\hline
\end{tabular}

Table 2: Serotyping of salmonellae isolated from the examined samples of fresh water fishes

\begin{tabular}{|c|c|c|c|c|c|c|}
\hline \multirow{3}{*}{ Serotypes } & \multicolumn{3}{|c|}{ Fish species } & \multirow{3}{*}{ Group } & \multirow{2}{*}{\multicolumn{2}{|c|}{ Antigenic structure }} \\
\hline & \multirow{2}{*}{$\begin{array}{c}\text { Tilapia niloticus } \\
\text { No }(\%)\end{array}$} & \multirow{2}{*}{$\begin{array}{c}\begin{array}{c}\text { Mugil } \\
\text { cephalus }\end{array} \\
\text { No }(\%) \\
\end{array}$} & \multirow{2}{*}{$\begin{array}{l}\begin{array}{l}\text { Clarias } \\
\text { lazera }\end{array} \\
\text { No }(\%) \\
\end{array}$} & & & \\
\hline & & & & & $\mathrm{O}$ & $\mathrm{H}$ \\
\hline S. typhimurium & $3(7.5)$ & $6(15)$ & $4(10)$ & B & $1,4,5,12$ & $\mathrm{i}: 1,2$ \\
\hline S. infantis & $1(2.5)$ & $1(2.5)$ & $3(7.5)$ & $\mathrm{C} 1$ & 6,7 & $\mathrm{r}: 1,5$ \\
\hline S. virchow & $2(5)$ & $1(2.5)$ & $2(5)$ & $\mathrm{C} 1$ & $6,7,14$ & $\mathrm{r}: 1,2$ \\
\hline S. enteritiditis & $2(5)$ & $5(12.5)$ & $2(5)$ & D1 & $1,9,12$ & $\mathrm{~g}, \mathrm{~m}$ \\
\hline S. heidelberg & 0 & $3(7.5)$ & $1(2.5)$ & B & $1,4,5,12$ & $\mathrm{r}: 1,2$ \\
\hline S. tsevie & 0 & $1(2.5)$ & 0 & B & 4,5 & $\mathrm{i}: \mathrm{e}, \mathrm{n}, \mathrm{z} 15$ \\
\hline S. wingrove & 0 & $2(5)$ & 0 & $\mathrm{C} 2$ & 8,20 & $\mathrm{c}: 1,2$ \\
\hline Total (120) & $8(20)$ & $19(47.5)$ & $12(30)$ & & & \\
\hline
\end{tabular}

Table 3: Incidence of virulence genes of different salmonella strains isolated from the examined samples of fish.

\begin{tabular}{llll}
\hline $\begin{array}{l}\text { Salmonella } \\
\text { serovars }\end{array}$ & $\begin{array}{l}\text { No. of } \\
\text { isolates }\end{array}$ & invA & hila \\
\cline { 3 - 4 } & & No (\%) & No (\%) \\
\hline S. typhimurium & 4 & $4(100)$ & $3(75)$ \\
\hline S. infantis & 4 & $4(100)$ & $2(50)$ \\
\hline S. virchow & 4 & $4(100)$ & $2(50)$ \\
\hline S. enteritidis & 3 & $3(100)$ & $3(100)$ \\
\hline S. heidelberg & 1 & $1(100)$ & $1(100)$ \\
\hline S. tsevie & 1 & $1(100)$ & $1(100)$ \\
\hline S. wingrove & 1 & $1(100)$ & 0 \\
\hline
\end{tabular}




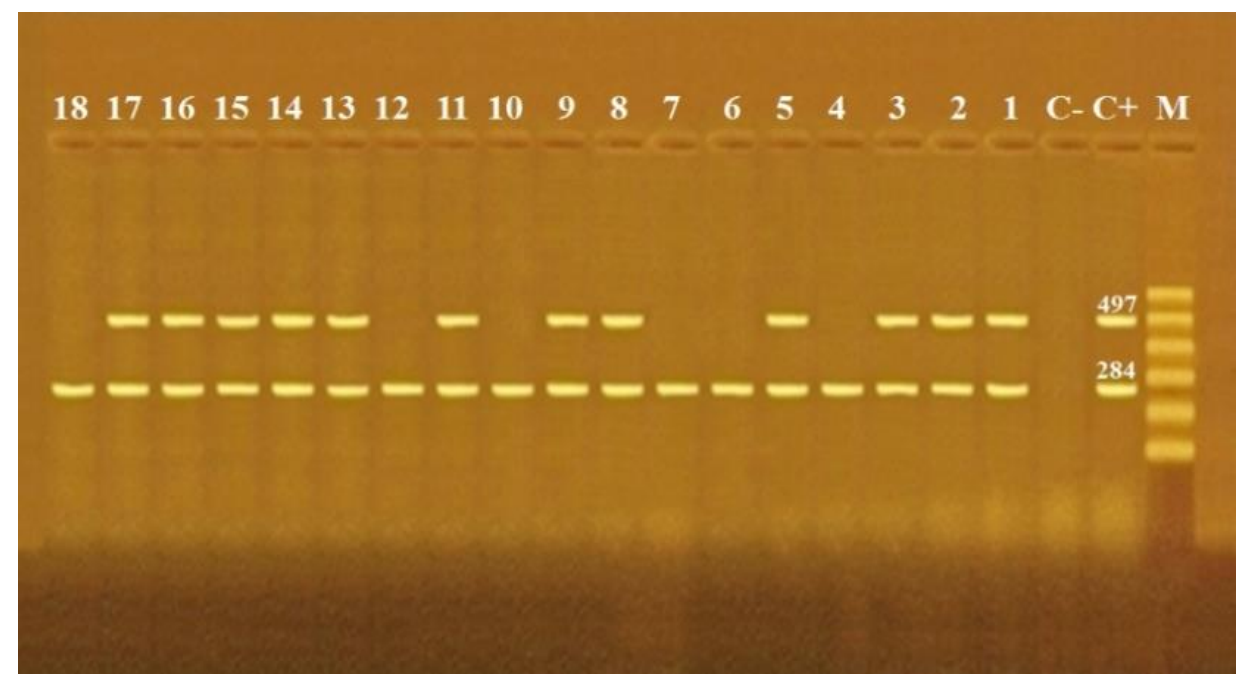

Figure 1: Agarose gel electrophoresis of multiplex PCR of invA (284 bp) and hilA (497 bp) virulence genes for characterization of salmonella species. Lane M: $100 \mathrm{bp}$ ladder; lane C+: Control positive strain for invA and hilA genes; lane C-: Control negative; lanes 1-18 isolated samples.

\section{Discussion}

In the present study, we found high incidence of salmonella pathogen among different fish species with highest rate in Mugil cephalous $(47.5 \%)$, followed by Clarias lazera (30\%), and then Tilapia niloticus (20\%). Higher incidence in Mugil cephalous may be due to its feeding nature as omnivorous bottom feeders swim over sandy-muddy bottom were they greases the pond detritus, organic matter and sediments which are usually of a high bacterial count (11) and salmonella can survive (54 days in water and up to 119 days in sediment) (12). This also may be due to the higher exposure of mugil species to contamination during their long transportation at high temperature from far cities as the point of production (farms) is so far from the point of distribution (fish markets) in Gharbia governorate. On the other hand, tilapia mainly inhabited shallow streams which are usually of a low bacterial count as a result of higher speed of water flow which prevent exceeding contamination with microorganisms, indicating the possibility of occurring cross contamination during offloading, landing and marketing of tilapia fish besides applying of poor hygienic practice via using of unsanitary water, ice and containers (13). And is not surprising in cat fish species since they mostly bred in area near from sewage which are usually related to fecal contamination of the water. Collectively, our findings are in consistence with (14) who reported that the variation in salmonella percentage in different types of fish could be attributed to fish species, environments, and methods of catch, extend of handling during transportation, distribution and storage. Our results partially agreed with (15) who also isolated different salmonella serotypes from fresh water fish (tilapia, mugil and catfish) from another locality in Egypt (Zagazig). However, this latter study showed a slight different in prevalence order, with highest rate in mugil samples (26.66\%), followed by Tilapia niloticus $(20 \%)$ then cat fish (13.3\%). This variations may be due to variety of factors such as geographical distribution, applying of poor personal hygine of fish handlers during sorting and selling, the degree of utensils contamination, the bacterial load of ice used for fish preservation and the time of sampling (16).

The results obtained from serological identification of the examined salmonella isolates revealed presence of 7 different salmonella serovars which are $S$. typhimurium, S. enteritidis, S. infantis, S. virchow, S.Heidelberg, $S$. wingrove and $S$. tsevie with a percentage of $33.3 \%, 23 \%, 12.8 \%, 12.8 \%, 10.25 \%, 5 \%$ and $2.5 \%$, respectively. These results agreed with (17) who reported that Salmonella typhimurium was the most frequently serovar isolated from 
Nile tilapia from Winam Gulf of lake victoria, kenia with a percentage of $14.3 \%$ regarding other salmonella serovars indicating its ability for survival and adaptation in the aquatic environment. This also was in consistence with WHO, (18) which reported that Salmonella typhimurium is the most common salmonella serotype isolated from cases of food poisoning and represents about 50-60\% of such cases. Many of these incidents have been linked to consumption of raw or improperly cooked fish and fish products.

It has been found that salmonella has a large number of genes which implicated in its virulence. Many of these virulent genes are chromosomal genes located on the pathogenicity islands referred to as salmonella pathogenicity island (spI) which is a part of type 3 secretion systems (T3SS) and encoded genes like invA, and hilA allowing some salmonella species to invade the host cells and induce infection. Our obtained PCR results revealed that invA gene was present in all the isolates with a percentage of $100 \%$. Meanwhile, hila gene was present only in $66.6 \%$ of all the isolates. Other studies have reported similar results (19-22) indicating that invA gene can be used as a specific target for detection of salmonella as they are widely distributed among salmonella serovars reflecting the potential virulence of these isolates. These finding play a great role in determining the severity of the microbe since invA gene was found to be present and functional in most if not all salmonella serotypes responsible for the invasion of the cells of the intestinal epithelium allowing salmonella pathogen to enter and survive inside the eukaryotic cells with subsequent diseases in variety of hosts. In this regard, it has been used in determining the presence and metabolic activity of salmonella species (23). Meanwhile, hilA gene is required for regulation of type 3 secretion apparatus genes which secret proteins that are related to cell invasion [13]. And has been used in detecting of S.enterica serovars from fecal samples according to [19]. In recent studies, it has been used as a diagnostic target to validate alternative methods for food analysis and food-borne pathogen detection instead of the standard method of ISO
6579, 2004 which are time consuming and can take up to 4-6 days for confirmative results.

\section{Conclusion}

Presence of salmonella as enteropathogens in fresh water fish can reflects the poor hygienic conditions under which fish have been captured, handled and transported. The main finding in our study was the high prevalence of salmonella pathogen with a diversity of serotypes in fresh water fish in gharbia governorate creating a high level of attention towards the hazards of presence of these zoonotic pathogens in marketed fish and their bad impact on public health. so, our study recommends a monitoring and surveillance programs to be adopted against the food borne-salmonella by applying a strict hygienic measures under the supervision of the food controlling authorities in order to control the keeping quality of the locally consumed fish and to protect the consumer from the risk of food poisoning associated with consumption of contaminated fish with such dangerous pathogens.

\section{Acknowledgements}

We thank Dr. Seham Elkassas, Poultry \& Fish Breeding \& Production Department, Kafrelsheikh University and Dr. Reda Abdallah, Food Control department, Kafrelsheikh University for their help.

\section{References}

1. Food and Agriculture Organization (FAO). 2014. The State of World Fisheries and Aquaculture 2014. Rome. 223.

2. El-Adawy M, El-Aziz M A, El-Shazly K, Ali N G, El-Magd M A. Dietary propionic acid enhances antibacterial and immunomodulatory effects of oxytetracycline on Nile tilapia, Oreochromis niloticus, Environmental Science and Pollution Research. DOI: 10.1007/s11356-018-3206-5 2018.

3. Raufu I, Lawan F, Bello H, et al. Occurrence and antimicrobial susceptibility profiles of Salmonella serovars from fish in Maiduguri, sub-Saharah, Nigeria. The Egyptian J. Aqua. Res. 2014; 40 (1): 59-63.

4. Aberoumand, A. Estimation of microbiological variations in Minced Lean fish products. World J. Fish Mar. Sci. 2010; 2 (3): 204-7. 
5. Wong $M$ and Chen S. First detection of oqxAB in Salmonella spp. isolated from food. Antimicro. Agen. Chemothera. 2013; 57(1): 658-60.

6. McGuinness S, McCabe E and O'Regan E. Dolan, G. Duffy, C. Burgess, S. Fanning, T. Barry, and J. O'Grady. Development and validation of a rapid real-time PCR based method for the specific detection of Salmonella on fresh meat. Meat Sci. 2009; 83: 555-62.

7. Kauffman G. Kauffmann white scheme. J. Acta. Path. Microbiol. Sci. 1974; 61:385-393.

8. Shanmugasamy $M$, Velayutham $\mathrm{T}$ and Rajeswar J. Inv A gene specific PCR for detection of Salmonella from broilers. Vet. World, 2011; 4 (12): $562-4$.

9. Singh S, Singh H, Tewari S, Prejit $N$ and Agarwal R. Characterization of virulence factors among diverse Salmonella serotypes and sources. Adv. Anim. Vet. Sci., 2013; 1(2): 69-74.

10. Guo X, Chen J, Beuchat Land Brackett R. PCR detection of Salmonella enterica serotype Montevideo in and on raw tomatoes using primers derived from hilA. Appl. Environ. Microbiol. 2000; 66: 5248-52.

11. Abdelhamid A, Gawish M and Soryal K. Comparative study between desert cultivated and natural fisheries of mullet fish in Egypt, II-microbiological concern. J Agric Sci. 2007; 31(5):5681-7.

12. Moore B, Martinez E, Gay J, and Rice D. Survival of Salmonella enterica in freshwater and sediments, and transmission by the aquatic midge Chironomus tentans (chironomidae: diptera). Appl Environ Microbiol. 2003; 69:4556-60.

13. Food and Agriculture Organization (FAO). 2010. Expert Workshop on the application of biosecurity Measures to control Salmonella Contamınation in Sustainable aquaculture FAO Fisheries and Aquaculture Report No. 937 ISSN 20706987, Mangalore, India, 19-21 January 2010.

14. Wang S, Chen J, and Fan J. Quality changes in fresh Tilapia and Milkfish during refrigerated (4 degree C) and frozen (-15 degree C) storage J. Food during Analysis, 1994; 2(4):311 -6.

15. El Bayomi R, Darwish W, Abd El-Moaty A, and Gad T. Prevalence, antibiogram, molecular characterization and reduction trial of Salmonella typhimurium isolated from different fish species.
Japanese Journal of Veterinary Research 2016; 64(Supplement 2): S181-6.

16. Falcão J, Dias A, Correa E, and Falcão D. Microbiological quality of ice used to refrigerate food .J Food microb. 2002; 19(4): 269-76.

17. David O, Wandili S, Kakai R, and Waindi E. Isolation of Salmonella and Shigella from fish harvested from the Winam Gulf of Lake Victoria, Kenya. J. Infect. Dev. Ctries. 2014; 3: 99-104.

18. World Health Organization (WHO). 1997. Microbial aspects of food hygiene,technical Report Series, No. 598, pP.21 - 23. WHO, Geneva, Switzerland.

19. Bhatta D, Bangtrakulnonth A,

Tishyadhigama P, et al. Serotyping, PCR, phagetyping and antibiotic sensitivity testing of Salmonella serovars isolated from urban drinking water supply systems of Nepal. Lett. Appl. Microbiol. 2007; 44: 588-94.

20. Maria A. Non typhoid Salmonella gastroenteritis in pediatric patients from urban areas in the city of Mérida, Venezuela. J. Infect. Developing Countries 2009; 3: 28-34.

21. Oliveira S, Rodenbusch C, Michae G, et al. Detection of virulence genes in Salmonella Enteritidis isolated from different sources. Braz. J. Microbiol. 2003; 34: 123-.

22. Tekale A. Detection and Virulence Gene Characterization of Salmonella Isolates from Fish by Conventional and Molecular Methods. J. Vet. Pub. Hlth. 2015; 13 (1): 43-6.

23. Fey A, Eichler S, Flavier S, et al. Establishment of a real-time PCR-based approach for accurate quantification of bacterial RNA targets in water, using Salmonella as a model organism. Appl Environ Microbiol. 2004; 70: 3618-23.

24. Lesnick M, Reiner N, Fierer J, and Guiney D. 2001. The Salmonella spvB virulence gene encodes an enzyme that ADPribosylates actin and destabilizes the cytoskeleton of eukaryotic cells. Mol Microbiol 39: 1464-70.

25. Pathmanathan S, Cardona-Castro N, Sanchez-Jimenez M, et al. Simple and rapid detection of Salmonella strains by direct PCR amplification of the hilA gene. J Med Microbiol. 2003; 52: $773-6$. 